\title{
The male role in cervical cancer
}

\author{
Xavier Castellsagué, MD, MPH, PhD,(1) F X avier Bosch, MD, PhD, (1) \\ N ubia Muñoz, MD, MPH.(2)
}

\section{Castellsagué X, Bosch FX, Muñoz N. \\ The male role in cervical cancer. \\ Salud Publica Mex 2003;45 suppl 3:S345-S353. \\ This paper is available too at: http://www.insp.mx/salud/index.html}

\begin{abstract}
A bstract
Experimental, clinical, and epidemiological evidence strongly suggests that genital H uman Papillomaviruses (HPVs) are predominantly sexually transmitted. Epidemiological studies in virginal and HPV-negative women clearly indicate that sexual intercourse is virtually a necessary step for acquiring H PV.As with any other sexually transmitted disease (STD) men are implicated in the epidemiological chain of the infection. Penile HPVs are predominantly acquired through sexual contacts. Sexual contacts with women who are prostitutes play an important role in HPV transmission and in some populations sex workers may become an important reservoir of highrisk H PV s.Acting both as "carriers" and "vectors" of oncogenic HPV s male partners may markedly contribute to the risk of developing cervical cancer in their female partners. Thus, in the absence of screening programs, a woman's risk of cervical cancer may depend less on her own sexual behavior than on that of her husband or other male partners. Although more rarely than women, men may also become the "victims" of their own HPV infections as a fraction of infected men are at an increased risk of developing penile and anal cancers. Male circumcision status has been shown to reduce the risk not only of acquiring and transmitting genital HPVs but also of cervical cancer in their female partners. More research is
\end{abstract}

\section{Castellsagué X, Bosch FX, Muñoz N. \\ El papel del varón en el cáncer cervical. \\ Salud Publica Mex 2003;45 supl 3:S345-S353. \\ Este artículo también está disponible en: \\ http://www.insp.mx/salud/index.html}

\section{Resumen}

Evidencia experimental, clínica y epidemiológica demuestra que los papilomavirus humanos (VPH) genitales son predominantemente de transmisión sexual. Estudios experimentales en mujeres vírgenes y en mujeres VPHnegativas indican de forma clara que el coito es virtualmente un paso necesario para adquirir el VPH. Como ocurre con cualquier otra infección de transmisión sexual (ITS) los varones están implicados en la cadena epidemiológica de la infección. LOS VPH en el pene son predominantemente adquiridos a través de contactos sexuales. Los contactos sexuales con mujeres que ejercen el sexo comercial juegan un papel importante en la transmisión de losVPH y en algunas poblaciones estas mujeres pueden convertirse en un importante reservorio deVPH de alto riesgo.Actuando ambos como "portadores" y "vectores" de losVPH oncogénicos los hombres pueden aumentar de forma substancial el riesgo de propiciar cáncer de cérvix en sus parejas. En ausencia de programas de detección precoz, el riesgo de cáncer de cér vix en una mujer puede depender menos de su conducta sexual que de la de su marido u otras parejas sexuales.Aunque más raramente que en las mujeres, los hombres pueden también convertirse en "víctimas" de sus propias infecciones por el $\mathrm{VPH}$, pues una fracción de hombres infectados tiene un riesgo

This work was partially supported by the Institut Català d'O ncologia, Spain, the International Agency for Research on Cancer, France; the Fondo de Investigaciones Sanitarias (FIS), Spain (grants 01/1237, 01/1236, and BAE 01/5013); and a Yamagiwa-Yoshida Memorial UICC International Cancer Study Grant.

(1) Institut Català d'O ncologia (IC O ). Servei d'Epidemiologia i Registre del C àncer. L'H ospitalet de Llobregat (Barcelona), Spain.

(2) International A gency for Research on C ancer (IARC). Unit of Field and Intervention Studies. Lyon, France.

Received on: September 17, 2002 • Accepted on: February 26, 2003

Address reprint requests to: Dr. Xavier Castellsagué. Institut Català d' O ncologia. Servei d'Epidemiologia i Registre del Càncer. Gran Via s/n, Km 2.7, 08907 L'H ospitalet de Llobregat. Barcelona, Spain.

E-mail: xcastellsague@ ico.scs.es 
needed to better understand the natural history and epidemiology of HPV infections in men.This paper is available too at: http://www.insp.mx/salud/index.html

Key words: cervix neoplasms; human papillo mavirus; sexually transmitted infections; male role aumentado de desarrollar cáncer de pene y de ano. Se ha mostrado que la circuncisión masculina puede reducir el riesgo no sólo de adquisición y transmisión del VPH genital, sino también de cáncer cervical en las parejas de hombres circuncisos. Se requieren más estudios científicos para entender mejor la historia natural y la epidemiología de las infecciones por el VPH en el hombre. Este artículo también está disponible en: http://www.insp.mx/salud/index.html

Palabras clave: neoplasmas del cuello uterino; papillomavirus humano; infecciones sexualmente transmisibles; papel masculino
$\mathrm{E}$ pidemiological studies in virginal and Human Papillomavirus (HPV)-negative women clearly indicate that sexual intercourse is virtually a necessary step for acquiring HPV as detected by HPV DNA and serum antibodies testing. Genital HPVs are predominantly sexually transmitted. As with any other sexually transmitted infection (STI) men are implicated in the epidemiological chain of the infection. Acting both as "carriers" and "vectors" of oncogenic HPVs, male partners may be important contributors to the risk of developing cervical cancer in their female partners. Although more rarely than women, men may also become the "victims" of their own sexual behavior and of their own HPV infections, and a fraction of infected men are at an increased risk of developing penile and anal cancers, two tumors that are strongly related to infection by the same HPV types that cause cervical cancer.

This chapter reviews and summarizes the accumulated evidence showing the importance of the male role in cervical carcinogenesis. We first show ecological evidence correlating sexual behavior patterns with cervical cancer incidence rates in different populations. We also review the evidence for a role of men in HPV transmission and cervical cancer risk.

\section{Sexual behavior patterns and incidence of cervical cancer: An ecological approach}

The hypothesis

The extent to which males contribute to the risk of HPVrelated cancers in a particular population mainly depends on two factors: the overall pattern of sexual behavior in the population as a whole, and on its related background HPV prevalence. This concept is not new and it was first formally proposed by Skegg and colleagues back in 1982, well before HPV was identified as the causal agent of cervical cancer. ${ }^{1}$
These investigators hypothesized that, in some populations, "a woman's risk of cervical cancer will depend less on her own sexual behavior than on that of her husband or other male partners." Without data on HPV prevalence at hand, they put forward the idea that cervical cancer incidence rates in an unscreened population will vary according to three different sexual behavior patterns. "Pattern A", would be observed in non promiscuous communities in which both men and women are mainly lifetime monogamous. "Pattern B", would be the one observed in some Latin American societies in which while women are expected to be lifetime monogamous men have many sexual partners. And "Pattern C", would be observed in a more permissive society in which both men and women tend to have several partners. Skegg's model thus predicted that cervical cancer incidence rates would be lowest in "Pattern A" communities, in which men and women are mostly monogamous, and highest in "Pattern B" communities, in which many men have intercourse with a small number of highly promiscuous women, frequently sex workers who constitute a reservoir of HPV infection.

The data: the IARC studies on the male role

Between 1985 and 1993 the International Agency for Research on Cancer (IARC) conducted a series of casecontrol studies in countries with low, intermediate and high incidence rates of cervical cancer to assess the role of HPV and other STIs in the etiology of this cancer. ${ }^{2-15}$ Husbands or current stable sexual partners of the women recruited in these studies were also invited, interviewed, and their penile samples tested for HPV DNA detection by state-of-the-art Polymerase Chain Reaction (PCR) techniques. This was accomplished in 1925 men enrolled in seven case-control studies carried out in Colombia, Brazil, Thailand, The Philippines, and 
Spain. This design allowed, almost 20 years later, the testing of Skegg's hypothesis by analyzing individually-collected data on HPV infection and sexual practices in adult men and women.

The distribution of the lifetime number of sexual partners in men and women is plotted in Figure 1 for two selected countries that have a 5 -fold ratio of cervical cancer incidence rates: Colombia, (age-adjusted incidence rate [AAIR] of 34.4 per 100000 women), and Spain (AAIR of 7.1). The curve for Colombia, closely resembles that hypothesized in Skegg's "Pattern B" society, with women being mostly monogamous (around $70 \%$ ), and men highly promiscuous (55\% of men had 20 or more sexual partners). In contrast, the corresponding distribution in Spain, although not identical, is consistent with Skegg's "Pattern A" society, with the vast majority of women being monogamous (around $90 \%$ ), and a small fraction of men highly promiscuous ( $15 \%$ of men had 20 or more sexual partners). Clearly, the male to female disparity in terms of number of sexual partners is more marked in high-risk Colombia than in low-risk Spain, confirming thus the contrasting cervical cancer incidence rates predicted by Skegg's model.

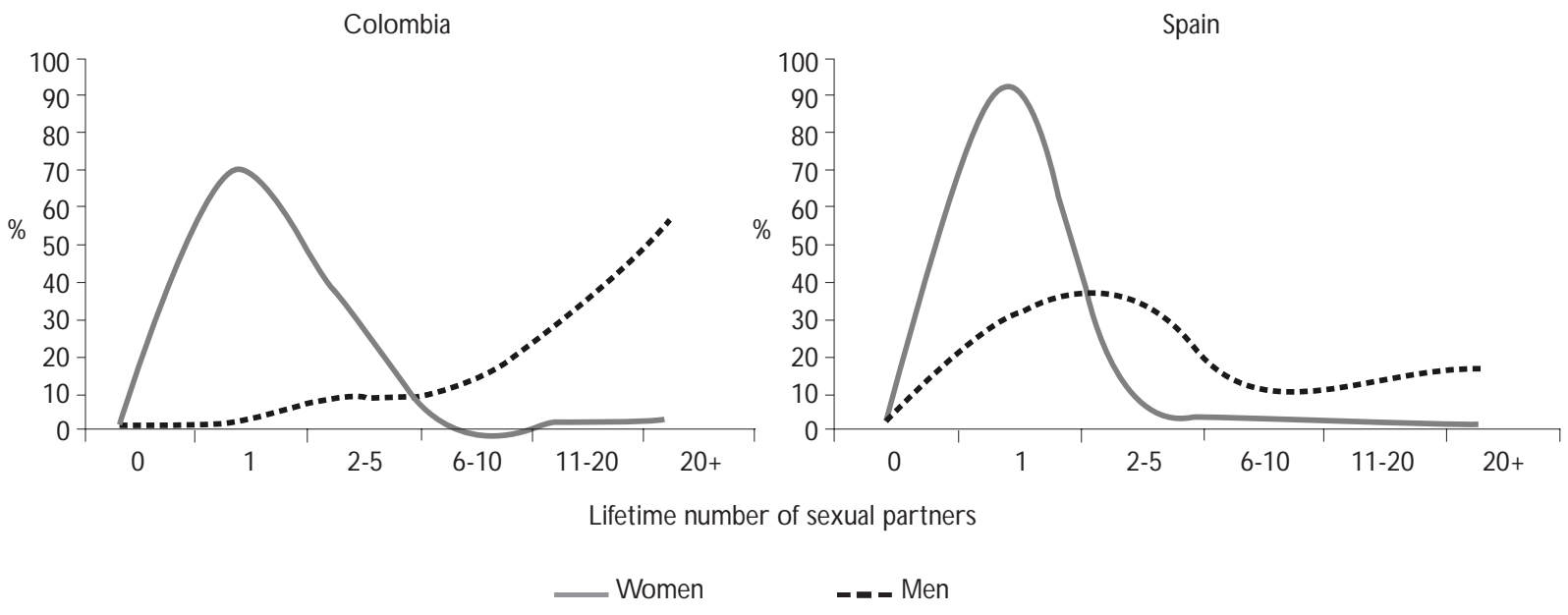

Figure 1. Distribution of lifetime number of Sexual partners in adult men and women in Colombia and Spain

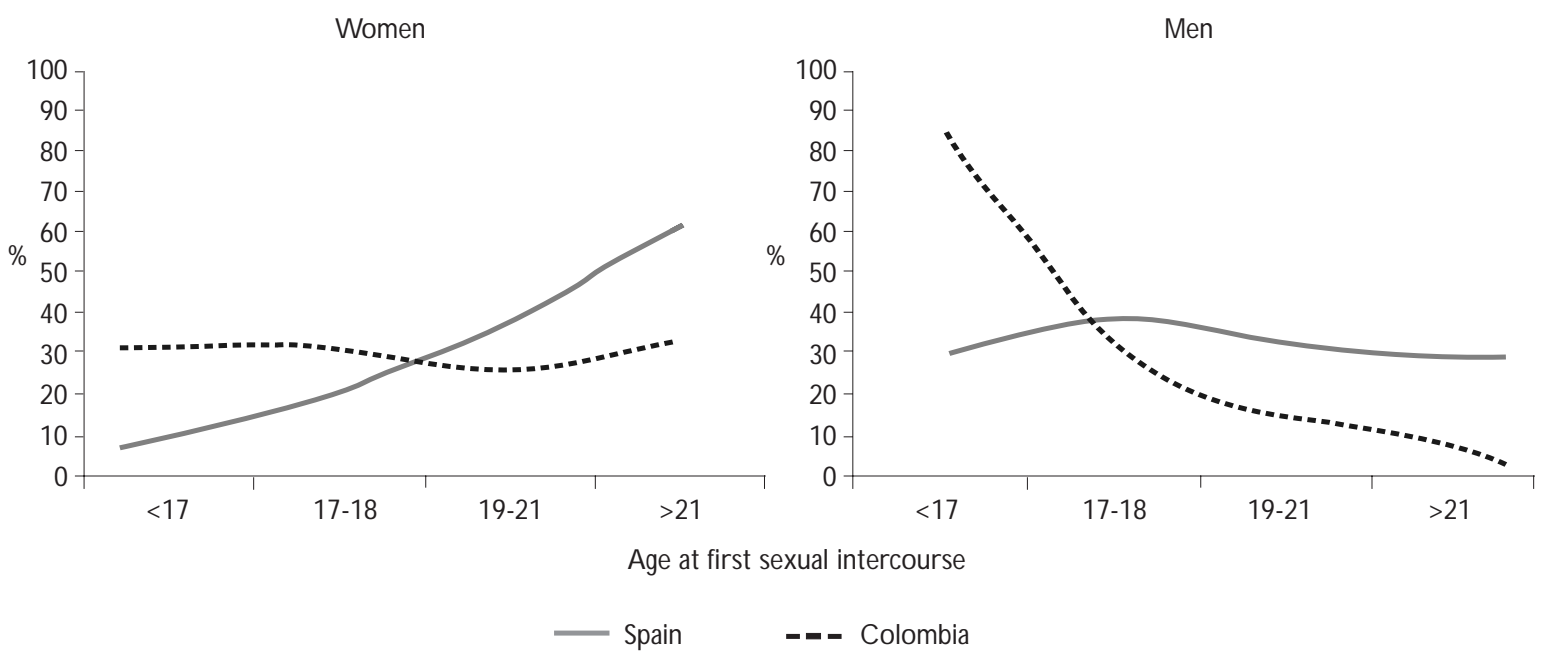

Figure 2. Distribution of age at first sexual intercourse in adult men and women in Colombia and Spain 
In parallel with these findings the distribution of age at first sexual intercourse, a sexual behavior indicator consistently found to be associated with cervical cancer risk even after taking into account HPV, greatly differed between Colombia and Spain (Figure 2). It was remarkable that, for this variable, the between-country disparity was observed both in men (68\% versus $24 \%$ men initiated sex at age 16 or younger in Colombia and Spain, respectively), and in women $(26 \%$ versus $6 \%$ women, initiated sex at age 16 or younger in Colombia and Spain, respectively).

These studies further found that the prevalence of reported ever contacts with prostitutes (79\% in Colombia versus 52\% in Spain) correlated also with cervical cancer, as it did the fraction of men's sexual partners than were prostitutes $(28 \%$ versus $10 \%$ men had more than 50 partners that were prostitutes in Colombia and Spain, respectively).

Concerning HPV infections in men and women the results from these studies show that penile HPV correlates better than cervical HPV with cervical cancer incidence rates. In Colombia, men had a higher HPV prevalence than women (19\% versus $15 \%$, respectively). In Spain, HPV prevalences for both men and women were 5 to 6 -fold lower than those in Colombia, and men had a lower HPV prevalence than women ( $3 \%$ versus $5 \%$, respectively).

\section{The role of men in cervical carcinogenesis}

Male sexual behavior and cervical neoplasia in sexual partners

Although the implication of a sexually transmitted agent in the etiology of cervical cancer has been suggested since the 1940 's ${ }_{1}{ }^{16}$ most early studies focused on the analysis of female's sexual behavior and on the testing of female's biological samples, paying little attention to the potential contribution of men. However, as with any other STD, studies in couples should provide consistent evidence of the venereal nature of HPVs and one would expect higher rates of HPV infection and HPV-related diseases in women who had sexual contacts with promiscuous men than in women who had contacts with non-promiscuous men. Indeed, this was already reported more than 30 years ago by Pridan and colleagues who showed for the first time an association between the number of sexual partners of the husband and the risk of cervical cancer among mostly monogamous Jewish women. ${ }^{17}$

Since the women themselves may also have had multiple sexual partners, the evidence for a role of men in HPV transmission is more clearly shown in studies of couples whose female consort claim to have had no sexual partners other than her husband or stable partner. This was shown for the first time by Buckley and colleagues who found that the risk of cervical cancer among monogamous women greatly increased with the number of sexual partners their husbands had had. Other male factors found to increase risk in this study were an early age at first intercourse, extramarital affairs, and history of STDs. ${ }^{18}$

The potential importance of the male role was also suggested in early studies of marital clusters. One study reported that subsequent wives of husbands whose previous wife developed cervical cancer had an increased risk of cervical neoplasia, ${ }^{19}$ and several studies have shown that wives of men with cancer of the penis have a higher incidence and mortality rates of cervical cancer. ${ }^{20-22}$

Studies showing geographic clustering of cervical and penile cancers, ${ }^{23-25}$ and studies showing strong correlation between incidence rates of male and female genital cancers, ${ }^{22,26}$ provided further ecological support on the importance of men in the natural history of cervical cancer.

More recently, data from the Swedish Family Cancer Database showed that husbands of women with in situ or invasive cervical cancer had an excess risk of anal cancer, a recognized HPV-related cancer. ${ }^{27}$ Anal cancer was also increased as a second primary cancer in women with cervical neoplasia. ${ }^{28}$ Of special interest is also the excess risk found in husbands of cervical cancer patients of both tonsilar cancer and cancer of the tongue, supporting the currently emerging evidence that HPV may be etiologically involved in a fraction of these tumors. ${ }^{29}$

All together these studies provide thus indirect evidence that: a) cervical and penile cancers share a common infectious etiology, b) both men and women contribute to the transmission of an infectious agent, and c) both men and women may become cancer victims of this viral infection.

Stronger evidence of the male role has been provided by formal case-control studies comparing either direct histories of sexual behavior or clinical evidence of HPV-related lesions in male partners of women with and without cervical cancer., ${ }^{2,13,30-32}$ Zunzunegui and colleagues showed, for instance, that as compared to unaffected women, women with cervical neoplasia were five times more likely to be married to a man who had had more than 20 sexual partners. ${ }^{30}$ In another study, women who were the sole sexual consorts of men with pre-existing penile condyloma showed an increased risk of cervical neoplasia. ${ }^{33}$ Barrasso and colleagues also 
reported a high prevalence of HPV-related penile neoplasia in the sex partners of women with cervical neoplasia. ${ }^{34}$

\section{Penile HPV DNA and risk of cervical cancer}

After the identification of HPVs as the sexually transmitted agents etiologically linked to cervical cancer, firm evidence for a role of men as carriers and vectors of oncogenic HPVs stemmed from studies that introduced HPV DNA detection in penile samples.

The largest study to date exploring the male role in cervical carcinogenesis is the multicentric case-control study coordinated by the IARC (Lyon, France). As explained in a previous section this large study involved over 1900 couples that were enrolled in seven case-control studies of cervical cancer carried out in Spain, Colombia, Brazil, Thailand, and the Philippines and in whom exfoliated penile cells were collected in men for HPV DNA detection. 2,3,5,6,8,9,11,13,15 Pooled data from these studies clearly indicate that the overall penile HPV prevalence clearly increases with increasing lifetime number of sexual partners of the men and with and early age at sexual debut (Figure 3). If we take also into account the sexual behavior of the female consort in the studies conducted in Spain ${ }^{2}$ and Colombia ${ }^{13}$ we can see that penile HPV prevalences were systematically higher in husbands of non-monogamous women than in husbands of monogamous women (Figure 4). Furthermore, the increasing trend between penile HPV and number of sexual partners of men was observed in the partners of both monogamous and non-monogamous women. ${ }^{7}$

Results for the IARC studies conducted in low- to intermediate-risk countries (i.e., Spain, Thailand and the Philippines), also indicate that the men's lifetime number of sexual partners, including female prostitutes as sexual partners, is one of the key determinants of cervical cancer risk in their wives. In Spain, the presence of HPV DNA in the husband's penis conveyed a 5fold increased risk of cervical cancer to their wives. The odds of cervical cancer among monogamous women increased up to 9.5-fold in relation to the presence of high-risk HPV types in the penis of their husbands. The excess risk associated with HPV type 16 was 6- to 9fold. Furthermore, the prevalence of penile HPV showed a positive trend with increasing number of sexual partners and with the number of sexual partners who were prostitutes. ${ }^{2}$ In contrast, in high-risk countries such as Colombia and Brazil, no associations with cervical cancer risk were found with penile HPV DNA or with other indicators of male sexual behavior. ${ }^{13}$

The lack of association between most male-related variables and cervical cancer risk found in high-risk countries could be explained by the fact that in these populations HPV is such a widespread infection that hampers case-control studies to discriminate subjects at a higher risk. In these populations, women's having sexual contacts with an even limited number of male partners place them at a high risk of acquiring cervical HPV infections and subsequent cervical cancer. HPV DNA detection in the penis of adult men, even if high,
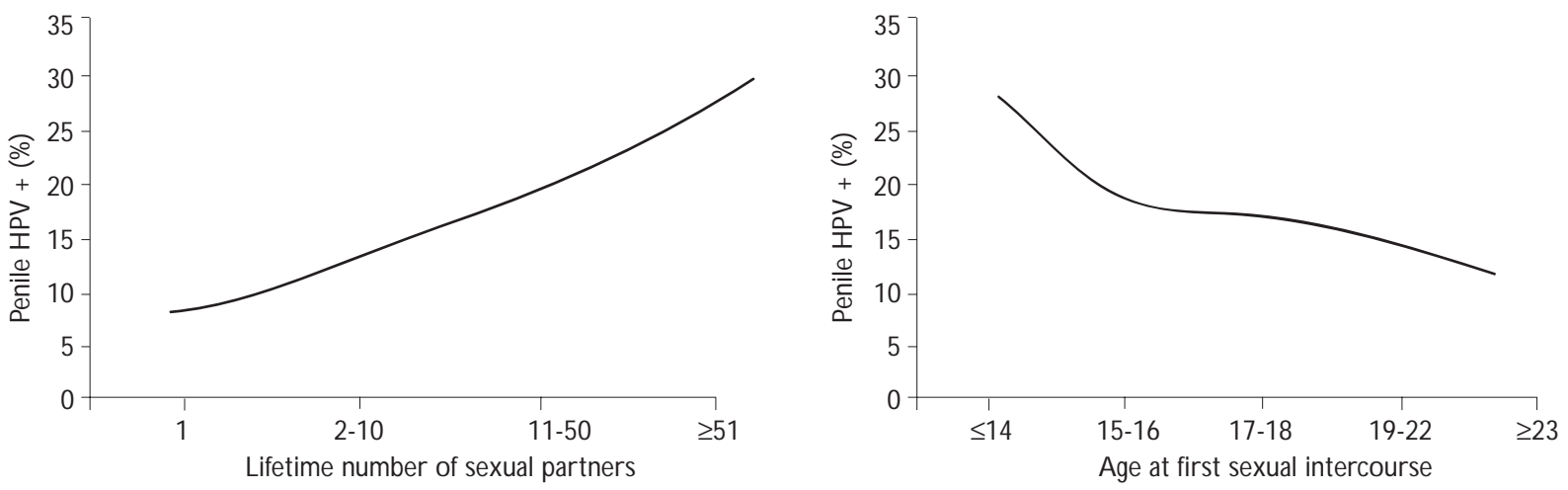

Data is based on 1140 men who were husbands or current stable partners of women recruited in one of seven case-control studies of cervical cancer carried out by the IARC in Colombia, Brazil, Spain, Thailand, and the Philippines

Figure 3. Prevalence of penile hPV DNA by lifetime number of sexual partners and age at first sexual INTERCOURSE (IARC STUDIES) 


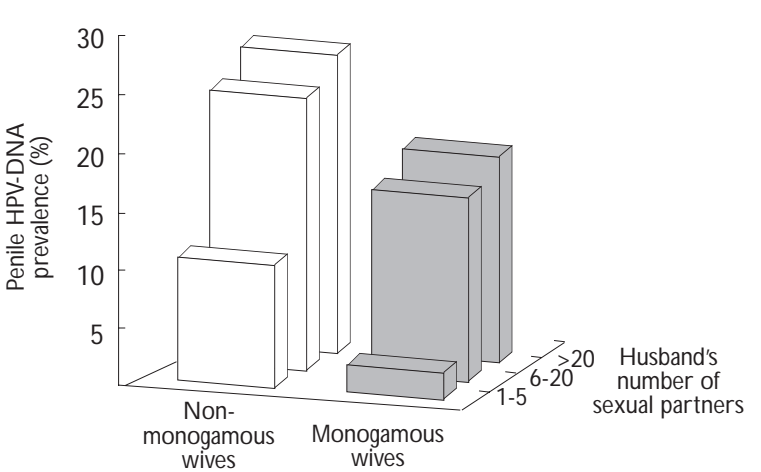

Source: Data is adapted from Castellsague et $\mathrm{l}^{7}$ and includes 595 men that were husbands or stable coital partners of women with and without cervical cancer

Figure 4. Penile hPV DNA prevalence by number OF SEXUAL PARTNERS OF HUSBANDS OF MONOGAMOUS AND non-monogamous women in Spain and Colombia

is still a poor reflection of lifetime exposure to HPV. Other biological markers of lifetime sexual promiscuity in men such as seropositivity to Chlamydia trachomatis have proved to better discriminate men's partners at a high risk of cervical cancer, not only in populations at low risk, ${ }^{2}$ but also in populations at high risk of cervical cancer. ${ }^{13}$

\section{$H P V$ concordance in couples}

Several studies have addressed concordance of genital HPVs in heterosexual couples. Most, but not all, ${ }^{35}$ of these studies found a relatively poor correlation of HPV-positivity and types in cervical and penile samples. ${ }^{7,10,36-38}$ The low agreement may be partly due to technical reasons, since a smaller amount of penile exfoliated cells may be obtained in men relative to the cellular yield obtained from the cervix. In some couples, the partner who has been sampled may not be the relevant one in determining the woman's risk of HPV persistence and progression to cervical neoplasia. Agreement in HPV findings, however, was also modest in couples where both the wife and husband reported only one lifetime sexual partner. ${ }^{10}$ In some of these studies the timing of the sampling of penile and cervical specimens at a relatively old age is the likeliest explanation for HPV discordance, since spontaneous regression of HPV infection is common in men ${ }^{39}$ and in women who do not develop cervical neopla- sia. ${ }^{40}$ Among women with cervical neoplasia, the relevant infection may have occurred many years earlier, and the relatively low prevalence of penile HPV infection in their husbands suggests that viral shedding of advanced cervical lesions is limited. Also point detection of penile HPV may measure relatively recent exposures to HPVs that may be unrelated to the initiation of cervical neoplasia in the wife.

\section{Male circumcision, penile HPV, and cervical cancer}

A recent piece of evidence confirming the importance of men in HPV transmission and cervical carcinogenesis comes from the IARC multicentric study on male circumcision. ${ }^{6}$ This study compared penile HPV DNA prevalence in circumcised and uncircumcised men to estimate a woman's risk of cervical HPV infection and that of cervical cancer according to the husband's circumcision status. We found that circumcised men were about three times less likely to harbor HPV in their penis than did uncircumcised men. Consistent with the venereal nature of HPV infections, we found that male circumcision also reduced the risk of both genital HPV infections and cervical cancer in the female partner. As shown in Figure 5 among monogamous women, circumcision status of the husband was associated with a reduced risk of cervical cancer, particularly and most strongly, among women whose male consorts had engaged in high-risk sexual behaviors as measured by an early age at first sexual intercourse, a high lifetime number of sexual partners, and sexual intercourse with women that were prostitutes. Furthermore, as shown in Figure 5, using a computed sexual behavior risk index revealed a statistically significant dose-response relationship between increasing husband's sexual behavior risk and cervical cancer risk reduction linked to circumcision in their wives. These findings confirmed for the first time the long-suspected hypothesis claiming that male circumcision might reduce the risk of cervical cancer in female partners and underlines the importance of the male in the risk of HPV acquisition and cervical neoplasia in the female partner.

The male role: Closing the epidemiological chain linking $H P V$ and cervical cancer

Even though males have traditionally been much less studied than women, in the last decade data from all sorts of epidemiological study designs assessing directly or indirectly the role of men in cervical carcinogenesis have been accumulating. The large IARC studies 


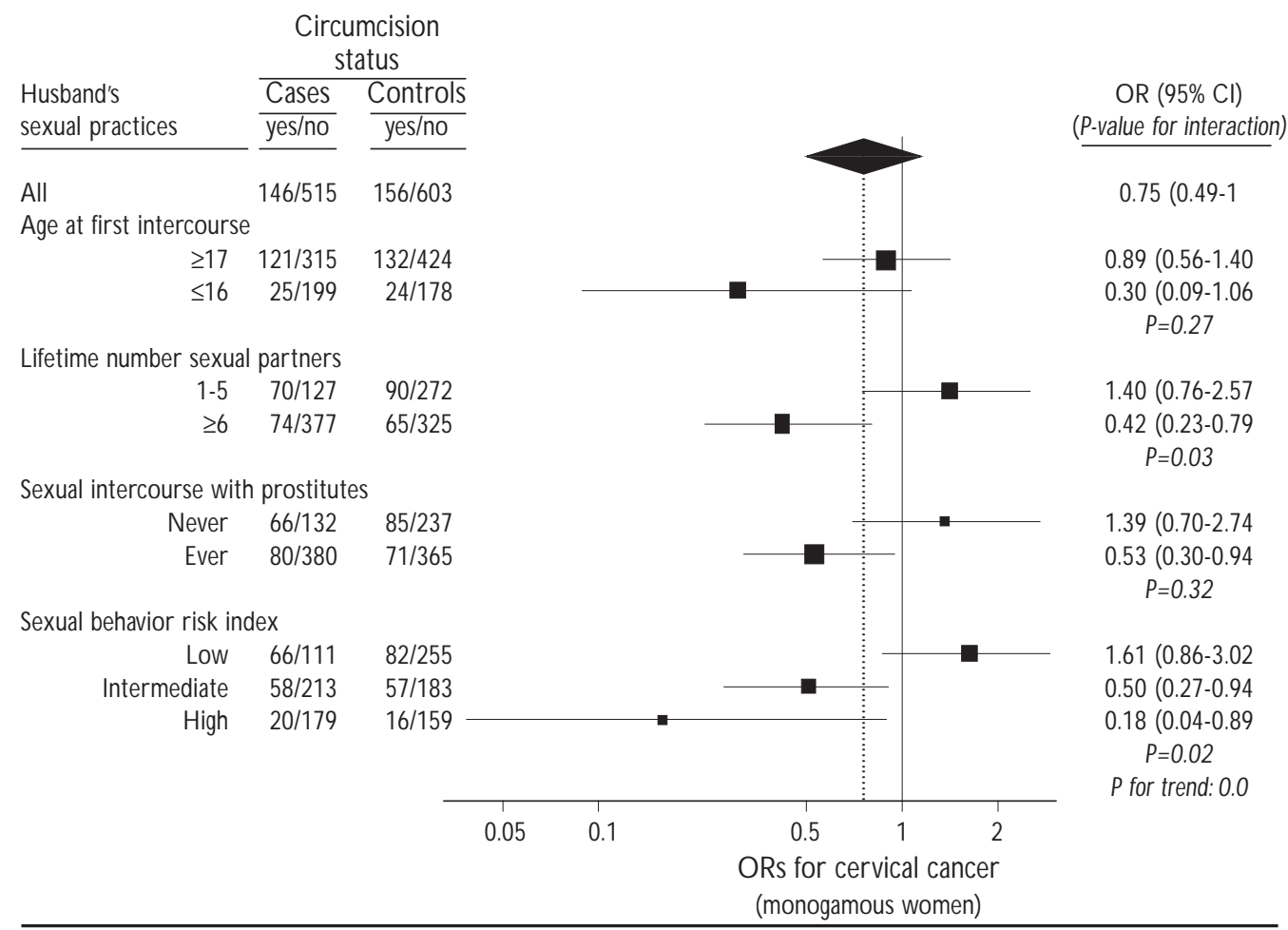

\begin{abstract}
* The black square and horizontal line represents the $0 \mathrm{R}$ and $95 \% \mathrm{Cl}$ for that stratum. The area of the black squares is proportional to the estimate's precision. The diamond represent the combined $\mathrm{OR}$ and $95 \% \mathrm{Cl}$. Husbands with a high sexual-behavior risk index were those with sexual debut before 17 years of age and six or more lifetime number of sexual partners. Husbands with a low sexual behavior risk index were those with a later sexual debut and a lower number of sexual partners. The remaining husbands were considered to have an intermediate sexual behavior risk index. For all models reference group is wives of uncircumcised men in that stratum. Models were adjusted by study, male's and female's age, male's education attained, male's age at first sexual intercourse, male's frequency of genital washing after sex, male's lifetime number of sexual partners, and female's age at first intercourse

Figure 5. Odds ratios for the association between male Circumcision and Cervical cancer in monogamous WOMEN ACCORDING TO HUSBANDS' SEXUAL BEHAVIOR CHARACTERISTICS*
\end{abstract}

on couples have shed new light on the largely unknown male side of the epidemiological chain of HPV and cervical cancer. ${ }^{2,6,7,10,13}$

Our current understanding is that men who have had multiple sexual partners or who are carriers of HPV DNA may be vectors of high-risk HPV types, placing their sexual partners at a high risk of cervical cancer. The key question though is how men acquire the virus in the penis in the first place. It is now well established that penile HPVs are predominantly acquired through sexual contacts. Sexual contacts with prostitutes play an important role in HPV transmission and sex workers may be an important population reservoir of high-risk HPVs. Through sexual intercourse with high-risk women, HPVs enter the penis which can then be transmitted to the current stable partner or to subsequent sexual partners. Men are thus the vectors of oncogenic HPV types that are usually found in cervical carcinomas. Circumcision is also likely to modulate the risk of penile
HPV acquisition, the risk of transmission to the partners as well as the long-term risk of cervical cancer.

At the ecological level, populations in which the sexual habits of men greatly differ from those of women, male promiscuity in general, and sexual contacts with prostitutes in particular, is likely. Under these circumstances, a woman's risk of being infected and develop cervical cancer depends much more on the sexual behavior of her partner than on that of her own. ${ }^{1}$

\section{Conclusions}

Experimental, clinical, and epidemiological evidence strongly suggests that genital HPVs are predominantly sexually transmitted. As with any STI men are implicated in the epidemiological chain. Penile HPVs are predominantly acquired through sexual contacts notably, at least in some populations, with prostitutes who become an important reservoir of high-risk HPVs. Act- 
ing both as "carriers" and "vectors" of oncogenic HPVs male partners may be important contributors to the risk of developing cervical cancer in their female partners. Male circumcision status has also been shown to influence not only the risk of acquiring and transmitting genital HPVs but also the risk of cervical cancer in women with promiscuous sex partners.

\section{Acknowledgments}

We thank Gina Albero for her assistance in statistical analyses and graph design.

\section{References}

1. Skegg D C, C orwin PA, Paul C, D oll R. Importance of the male factor in cancer of the cervix. Lancet 1982;2:581-583.

2. Bosch FX, C astellsagué X, Muñoz N, D e Sanjosé S, G haffari AM, González LC et al. Male sexual behavior and human papillomavirus DN A: Key risk factors for cervical cancer in Spain. J N atl C ancer Inst 1996:88:1060-1067.

3. Bosch FX, Muñoz N , De Sanjosé S, Guerrerro E, G haffari AM, Kaldor J, et al. Importance of human papillomavirus endemicity in the incidence of cervical cancer : An extension of the hypothesis on sexual behavior. Cancer Epidemiol Biomark Prev 1994;3:375-379.

4. Bosch FX, Muñoz N , D e Sanjosé S, Izarzugaza I, Gili M, Viladiu P et al. Risk factors for cervical cancer in Colombia and Spain. Int J Cancer 1992:52: 750-758.

5. Bosch FX, Muñoz N , De Sanjosé S, N avarro C, Moreo P,Ascunce N et al. Human papillomavirus and cervical intraepithelial neoplasia grade III/ carcinoma in situ:A case-control study in Spain and Colombia. Cancer Epidemiol Biomark Prev 1993;2:415-422.

6. Castellsagué X, Bosch FX, Muñoz N, Meijer CJ, Shah KV, De Sanjosé S et al. Male circumcision, penile human papillomavirus infection, and cervical cancer in female partners. N Engl J Med 2002;346:1105-1112. 7. C astellsagué $X, G$ haffari A, D aniel RW, Bosch $F X, M$ uñoz N, Shah KV. Prevalence of penile human papillomavirus DNA in husbands of women with and without cervical neoplasia:A study in Spain and Colombia.J Infect D is 1997;176:353-361.

8. Chichareon S, Herrero R, Muñoz N, Bosch FX, Jacobs MV, D eacon J et al. Risk factors for cervical cancer in Thailand:A case-control study. J $\mathrm{N}$ atl C ancer Inst 1998:90:50-57.

9. Eluf-N eto J, Booth M, Muñoz N, Bosch FX, Meijer CJ,W alboomers JM. Human papillomavirus and invasive cervical cancer in $\mathrm{Brazil}$. $\mathrm{Br} \mathrm{J}$ Cancer 1994;69:114-119.

10. Franceschi S, C astellsagué X, D al Maso L, Smith JS, Plummer M, $\mathrm{N}$ gelangel $\mathrm{C}$ et al. Prevalence and determinants of human papillomavirus genital infection in men. $\mathrm{Br}$ J C ancer 2002;86:705-711.

11. Muñoz N , Bosch FX, D e Sanjosé S, Tafur L, Izarzugaza I, Gili M et al. The causal link between human papillomavirus and invasive cervical cancer:A population-based case-control study in Colombia and Spain. Int J Cancer 1992;52:743-749.

12. Muñoz N, Bosch FX, De Sanjosé S, Vergara A, del Moral A, Muñoz MT et al. Risk factors for cervical intraepithelial neoplasia grade III/ carcinoma in situ in Spain and Colombia. Cancer Epidemiol Biomark Prev 1993;2: 423-431.

13. Muñoz N, C astellsagué X, Bosch FX, Tafur L, De Sanjosé S, A ristizabal $\mathrm{N}$ et al. Difficulty in elucidating the male role in cervical cancer in
Colombia, a high-risk area for the disease. J N atl C ancer Inst 1996;88:1068-1075.

14. Muñoz N , Kato I, Bosch FX, Eluf-N eto J, De Sanjosé S,Ascunce N et al. Risk factors for HPV DN A detection in middle-aged women. Sex Transm D is 1996;23:504-510.

15. N gelangel C, Muñoz N , Bosch FX, Limson GM, Festin MR, D eacon J et al. C auses of cervical cancer in the Philippines:A case-control study. J $N$ atl C ancer Inst 1998:90:43-49.

16. Rigoni-Stern A, Ricci JV, ed. 0 ne hundred years of gynaecology 1800 1900. Philadelphia: Blakiston C 0, 1945.

17. Pridan $\mathrm{H}$, Lilienfeld AM. C arcinoma of the cervix in Jewish women in Israel, 1960-67. An epidemiological study. Isr J Med Sci 1971;7:1465-1470. 18. Buckley JD, Harris RW, D oll R, Vessey MP,W illiams PT. C ase-control study of the husbands of women with dysplasia or carcinoma of the cervix uteri. Lancet 1981;2:1010-1015.

19. Kessler II.Venereal factors in human cervical cancer: Evidence from marital clusters. Cancer 1977;39:1912-1919.

20. Martinez I. Relationship of squamous cell carcinoma of the cervix uteri to squamous cell carcinoma of the penis among Puertorican women married to men with penile carcinoma. Cancer 1969;24:777-780.

21. Graham S, Priore R, Graham M, Browne R, Burnett W,W est D. Genital cancer in wives of penile cancer patients. C ancer 1979;44:1870-1874. 22. Smith PG, Kinlen LJ,W hite GC,Adelstein AM, Fox AJ. Mortality of wives of men dying with cancer of the penis. $\mathrm{Br}$ J C ancer 1980;41: 422-428.

23. Cartwright RA, Sinson JD. C arcinoma of penis and cervix. Lancet 1980;1:97.

24. Li JY, Li FP, Blot W J, Miller RW, Fraumeni JF Jr. Correlation between cancers of the uterine cervix and penis in China.J $\mathrm{N}$ atl $\mathrm{C}$ ancer Inst 1982; 69:1063-1065.

25. Macgregor JE, Innes G. C arcinoma of penis and cervix. Lancet 1980;1:1246-1247.

26. Bosch FX, C ardis E. Cancer incidence correlations: G enital, urinary and some tobacco- related cancers. Int J C ancer 1990;46:178-184.

27. Hemminki K, D ong C . C ancer in husbands of cervical cancer patients. Epidemiology 2000;11:347-349.

28. Hemminki K, D ong C, Vaittinen P. Second primary cancer after in situ and invasive cervical cancer. Epidemiology 2000;11:457-461.

29. Hemminki K, D ong C, Frisch M. Tonsillar and other upper aerodigestive tract cancers among cervical cancer patients and their husbands. Eur I C ancer Prev 2000:9:433-437.

30. Zunzunegui MV, King MC, Coria CF, Charlet J. Male influences on cervical cancer risk.Am J Epidemiol 1986;123:302-307.

31. Brinton LA, Reeves W C, Brenes MM, Herrero R, Gaitán E, Tenorio F et al.The male factor in the etiology of cervical cancer among sexually monogamous women. Int J Cancer 1989;44:199-203.

32. Kjaer SK, de Villiers EM, D ahl C, Engholm G, Bock JE, Vestergaard BF et al. C ase-control study of risk factors for cervical neoplasia in D enmark. I: Role of the "male factor" in women with one lifetime sexual partner. Int J Cancer 1991;48:39-44.

33. Campion MJ, Clarkson P, McC ance DJ. Squamous neoplasia of the cervix in relation to other genital tract neoplasia. C lin 0 bstet Gynaecol $1985 ; 12: 265-280$.

34. Barrasso R, De Brux J, Croissant 0, O rth G. High prevalence of papillomavirus-associated penile intraepithelial neoplasia in sexual partners of women with cervical intraepithelial neoplasia. N Engl J Med 1987;317: 916-923.

35. Baken LA, Koutsky LA, Kuypers J, Kosorok MR, Lee SK, Kiviat N B et al. Genital human papillomavirus infection among male and female sex partners: Prevalence and type-specific concordance.J Infect D is 1995;171: 429-432.

36. Hippelainen MI,Yliskoski M, Syrjanen S, Saastamoinen J, Hippelainen M, Saarikoski S et al. Low concordance of genital human papillomavirus 
(HPV) lesions and viral types in HPV-infected women and their male sexual partners. Sex Transm D is 1994;21:76-82.

37. Kyo S, Inoue M, Koyama M, Fujita M, Tanizawa O, Hakura A.

Detection of high-risk human papillomavirus in the cervix and semen of sex partners. I Infect D is 1994;170:682-685.

38. Strand A, Rylander E, W ilander E, Zehbe I. HPV infection in male partners of women with squamous intraepithelial neoplasia and/or highrisk HPV.Acta Derm Venereol 1995;75:312-316.
39. Hippelainen MI, Hippelainen M, Saarikoski S, Syrjanen K. Clinical course and prognostic factors of human papillomavirus infections in men. Sex Transm D is 1994;21:272-279.

40.W oodman C B, C ollins S, W inter H, Bailey A, Ellis J, Prior P et al. $N$ atural history of cervical human papillomavirus infection in young women:A longitudinal cohort study. Lancet 2001;357:1831-1836. 